point. But it is possible that he misunderstood the first news he received of the attack on Colet, and that the malevolorum blateramenta, to which he pays little heed, were really the kernel of the matter. We have no other letters from him to Colet till 31 Oct. $1513,{ }^{12}$ by which time the affair seems to have been concluded. He says-

De reddita quiete dici non potest quam tibi gratuler [at opening: and again at the end he adds] gratulatus sum proximis literis/et iterum gratulor, quod ad sanctissimos illos ac saluberrimos concionandi labores redieris. Arbitror enim cessatiunculam illam in bonum etiam versum iri, dum avidius andient cuius vocem aliquamdiu desyderarunt.

Colet's biographers agree in explaining this as a temporary suspension from preaching pronounced by Fitzjames, and they are probably right, though there is nothing in the words quoted from the end of Ep. 107 which could not apply to an interruption caused by illness. The account given by Erasmus in Ep. 435 may be taken as substantially correct; and it is quite possible that Fitzjames suspended Colet from preaching, perhaps for three months (cessatiuncula illa), while the case was being tried.

The identification suggested in this note indicates that Colet's friends were not pleased with Warham's action in the matter, and regarded him as having sided with the adversary. Probably they expected an entire acquittal and a triumphant removal of the suspension. Warham, though he sympathised with Colet's intellectual position, and had a warm affection for him, perhaps, while acquitting him, allowed the suspension to stand for the sake of ecclesiastical order, till it expired, thereby saving the bishop from an awkward position, but incurring the indignation of Erasmus, who was an ardent partisan of Colet. Of this indignation no trace remains in the letter of 1521 , either because Erasmus was not writing with the freedom permitted by the mysterious cloak of 'N.,' or perhaps we may conjecture that he was induced to take a more dispassionate view of the matter by Colet himself, whose relations with Warham remained quite unclouded by the episode.

It may be worthy of remark, in illustration of the caution with which Erasmus's correspondence must be used in its present form, that of the ten letters here quoted not one stands with its date correct and complete in either of the editions referred to.

P. S. Allen.

\title{
The Dialogue on Richelieu and his Policy.
}

Is the very interesting dialogue which Dr. Hodgkin published in the last number of the English Historical Review (ante, p. 20) there occur a number of French names - of people and places--woefully misspelt

18 Ep. 107, vi. 9. 
by the Italian scribe whose manuscript Dr. Hodgkin translates. In some cases the translator has suggested emendations or pointed out that the word as it stands cannot be correct. For the couvenience of those who refer to the dialogue in the future a few more explanations and comments may be attempted.

On p. 29 we have a list of the fortresses which Richelieu had under his control. The first name on the list is Brouage. Dr. Hodgkin suggests that we should read Bourges. But here the Italian is in the right: Richelieu became governor of the port of Brouage, over against Oléron, in $\mathbf{1 6 2 9}$. Next we are told how Richelieu 'artfully got possession of Granvelle, Havre, il Ponte dell' Arca, and Pontioche [?.Ponthieu], in France. In Brittany and Normandy he held Brest, Sanmaur, Angers, Amboise, the islands, and Olerui [? Oléron].' The suggestion of Oléron for 'Olerui' is certainly correct; but 'Pontioche' can hardly be Ponthieu, a district which Richelieu never held. More probably it is Pontoise. In his will (printed at the end of Aubery's life) the cardinal bequeathed his rights over this place to his nephew. 'Sanmaur' should no doubt be Saumur, another of the towns mentioned in the will. 'Il Ponte dell' Arca' is of course Pont de l'Arche, on the Seine above Elbœuf; and Granvelle must be Granville, in the Cotentin, also mentioned in the will.

On p. 30 the 'duchess of Ognana' is the duchess of Ornano, who was disgraced with the princess of Conti, as the Italian says. I cannot improve on Dr. Hodgkin's suggestion that ' $M$. de Tudeschin' is in reality M. de Tronçon, though the identification is not quite certain. On the same page we are told how 'the seigneurs Chaudebonne, Mondewie. [? Montaigu], and Ornano, brother of Marshal Ornano,' were imprisoned after the marshal's fall in 1626. 'Mondewie' cannot, I think, be Montaigu. The only person of that name whom the cardinal imprisoned was Walter Montague, son of the earl of Manchester, who was arrested in Lorraine at the very end of 1627 and sent to the Bastille. The person arrested with Chaudebonne is called in the Memoirs of Richelieu (iii. 72) and of Bassompierre (iii. 50) Modène. As the text calls this 'Mondewie'. an 'adherent' of Ornano and couples him with Chaudebonne it seems probable thet he is Modène.

.Finally on p. 45 we read how the king offered his mother 'the government of Angers, by means of Marshal Schomberg and the lord of Roysi [?], who were sent to her for this express purpose." There is no difficulty about the name of Schomberg'e companion. He was Jean Jacques de Mesme, sieur de Roissy, the father of the count d'Avaux.

J. H. Clapham. 